\title{
Current options concerning the endodontically-treated teeth restoration with the adhesive approach
}

\section{Marco Aurélio de CARVALHO(a) Priscilla Cardoso LAZARI(a) Marco GRESNIGT (b) Altair Antoninha DEL BEL CURY(c) Pascal MAGNE(d)}

(a) Universidade Federal de Goiás - UFG, Dental School, Department of Stomatology Sciences, Goiania, GO, Brazil.

(b) University of Groningen, University Medical Center Groningen, Direct Restorative Department, Groningen, The Netherlands.

(c) Universidade Estadual de Campinas Unicamp, Piracicaba Dental School, Department of Prosthodontics and Periodontology, Piracicaba, SP, Brazil.

(d) University of Southern California - USC, Herman Ostrow School of Dentistry, Division of Restorative Sciences, Los Angeles, CA, USA.

Declaration of Interests: The authors certify that they have no commercial or associative interest that represents a conflict of interest in connection with the manuscript.

Corresponding Author: Marco Aurélio de Carvalho E-mail:marco_carv@hotmail.com

https://doi.org/10.1590/1807-3107bor-2018.vol32.0074

Submitted: May 10, 2018

Accepted for publication: May 29, 2018

Last revision: June 12, 2018

\begin{abstract}
Adhesive procedures have changed the way to restore endodontically treated teeth (ETT). It started with the shift from cast post-and-core to fiber post. The original focus on strength also shifted towards failure modes, revealing that catastrophic failures are still a concern when restoring endodontically-treated teeth even with fiber posts. As an alternative, postless approaches have been proposed in order to improve the chances of repair. The goal of this critical review is to present a survey of the current knowledge on adhesive approaches to restore endodontically treated teeth with and without extensive coronal tissue loss. The preservation of tooth structure of endodontically treated teeth is paramount. Partial versus full coverage of ETT, the role of the ferrule, the post type effect on catastrophic failures and postless alternatives as endocrowns and postless build-ups are reviewed. There is a consensus that the remaining tooth structure plays an important role in ETT survival, although the current literature still is contradictory on the influence of post type on root fractures as well as the benefits of avoiding a post or partially restoring a tooth. More clinical studies should be carried out with the modern postless adhesive alternatives to conventional approaches.
\end{abstract}

Keywords: Tooth, Nonvital; Dental Materials; Crowns; Dental Restoration Failure; Dental Bonding.

\section{Introduction}

The optimal way to restore teeth after endodontic treatment continues to remain a controversial topic of heated debate to this day. Endodontically treated teeth (ETT) present with significantly different mechanical properties compared to vital teeth. ${ }^{1,2}$ The modifications in the biomechanical properties and structural integrity of the teeth are most-likely attributed to the volumetric loss of the hard tissues, extent of carious lesion, fracture propagation, final cavity preparation in addition to the access cavity prior to endodontic therapy. ${ }^{3,4,5,6,7}$

There is still a debate regarding which technique would be ideal for ETT restoration, since those teeth are considered to have a higher risk of fracture than vital teeth. $4,7,8,9,10$ From a biomimetic perspective, the preservation and conservation of tooth structure is paramount in maintaining the balance between biological, mechanical, adhesive, functional, and esthetic 
parameters. It is beneficial to preserve coronal tissues and avoid invasive endodontic procedures, because these approaches violate the biomechanical balance and compromise the long-term performance of restored teeth. ${ }^{11}$ As quantified by Dietschi et al, ${ }^{4}$ the cavity depth, isthmus width, and configuration are highly critical factors in determining the reduction in tooth stiffness and risk of fracture. The remaining vertical coronal tooth structure named "ferrule" is clearly considered the crucial factor for the optimal biomechanical behavior of endodontically treated teeth. ${ }^{12,13,14,15,16}$ However, sufficient coronal structure is sometimes deficient in clinical situations and the teeth do not offer enough sound structure to generate a ferrule effect.

The restorative approach regarding ETT has changed in recent years. The availability of proven and reliable adhesive dental techniques has expanded the restorative options for the clinician. Amalgam cores and cast metal posts are being replaced by direct composite and glass-fiber posts, in addition to all ceramic and composite resin crowns being often chosen because of their superior aesthetic outcome. ${ }^{17,18}$ Furthermore, restorations techniques without the use of post-and-core build-ups are gaining in popularity due to their minimal invasiveness and simplification of clinical steps. ${ }^{19,20}$ Clinicians still face the same dilemma when restoring ETT: should this tooth be restored with or without a post?

The aim of this critical review is to assess the literature on the recent trends in adhesive dentistry to restore the endodontically treated teeth.

\section{Preserving the coronal structure}

The restoration replacement can result in a restorative cycle of death and was first described by Elderton ${ }^{21}$ in 1988 and Simonsen ${ }^{22}$ in 1991. The defective restorations are eventually replaced by larger restorations that will someday fail again, which will lead to even larger restorations or possible post-andcore approach, increasing the risk for complications, and eventually loss of the tooth. ${ }^{23}$ The concept of minimal intervention in dentistry to preserve and conserve tooth structure is gaining popularity equally when restoring endodontically treated teeth. ${ }^{15,20,24}$
Tooth structure preservation and conservation is directly correlated with fracture resistance ${ }^{4,25}$ whilst reducing the occurrence of catastrophic failures and enhancing the longevity of the restored tooth. ${ }^{12,15}$

The first point to be discussed is the interruption/ enlargement of the restorative cycle of teeth by preserving and conserving sound tooth structure with modern adhesive partial restorations (preservation of extension) instead of tooth volumetric reduction for full contoured crowns (extension for prevention). Nevertheless, once the coronal structure has been reduced for full crown placement, the preservation of the reminiscent ferrule should be of most importance, as it may improve dramatically the survival of ETT. ${ }^{12,15}$ Another factor is precision and minimally invasiveness when replacing restorations on ETT with the aid of magnification, electric driven hand pieces and applying adhesive dental modalities.

\section{Partial restorations versus full crowns on ETT}

In the modern practice, a direct composite is often preferred over full crowns since additive adhesive restorations may prevent root fracture. ${ }^{17,26}$ The traditional approach in ETT is to place a post, core and a crown after the endodontic treatment. The need to place a crown on an ETT has been investigated in in vitro studies and clinical trials, ${ }^{27-29}$ however a recent Cochrane review was inconclusive because of a lack of suitable studies. ${ }^{28}$ It was concluded that there is no literature evidence to support placement of a crown over a direct restoration on severely broken down ETT.

Adhesive dentistry for tooth restorations should be taken in consideration when restoring ETT in current days, as post-and-core are associated with a full crown approach which was developed using nonadhesive luting, but rather a cementable restoration (porcelain fused to metal crown and cast post-and-core). Without the need of macro mechanical retention that is mandatory to retain a cementable restoration, most of sound dental tissue now can be preserved and conserved and partial restorations can be adhesively bonded to the remaining coronal structure, particularly to the enamel substrate, directly or indirectly. 
A recent randomized clinical trial ${ }^{27}$ compared the survival of composite resin restorations and porcelain fused to metal (PFM) crowns on ETT that received a glass-fiber post. The overall annual failure rate was $0.92 \%$ after 50 months of success of the restorations without difference for survival between the types of restoration. This was the first randomized clinical trial (RCT) including all tooth types and severely brokendown teeth comparing PFM crowns vs composite restorations. Although the study only assessed direct resin composite restorations, adhesive indirect partial restorations could possibly have provided a better outcome in terms of material aspects.

In a recent systematic review, Suksaphar et al. ${ }^{30}$ investigated the survival rate of posterior ETT restored with crowns or resin composite restorations. Three clinical studies were included: a RCT, ${ }^{31}$ a prospective ${ }^{32}$ and a retrospective cohort study. ${ }^{33}$ Pooled survival rates ranged from $94 \%-100 \%$ and $91.9 \%-100 \%$ for crowns and resin composite, respectively. The authors were not able to do a meta-analysis due to the heterogeneity of the studies. The authors concluded that survival rates of endodontically treated posterior teeth restored with crowns or resin composites were not significantly different to teeth with minimum to moderate loss of tooth structure. Therefore, preparing sound tooth structure in order to place a full contour crown may not be suitable anymore in a contemporary dental practice aided by adhesive dentistry.

Partial restorations like indirect onlays have been suggested as an alternative to full crowns as it preserves more sound tooth structure while providing cuspal coverage to protect weakened cusps. ${ }^{29}$ As cavity size increases, predominately after the endodontic access and the marginal ridges are lost, structural integrity decreases and flexibility increases. ${ }^{4}$ The use of alternative partial bonded restorations should be considered for certain clinical situations, due to their ability to preserve enamel. Direct or indirect bonded restorations for cuspal coverage have been advocated in order to eliminate the need for axial wall destruction. ${ }^{34}$ The use of composites has also allowed clinicians to adhesively restore teeth that would otherwise require extensive mechanical retention. The use of partial restorations is becoming increasingly popular and this also helps prevent tooth structure loss. There is no study that compares direct composite restorations with adhesive indirect restorations (ceramic partial restorations or ceramic crowns) and therefore more studies could be carried out in order to assess the real need of preparing sound tooth structure for a full crown restoration.

\section{The role of the ferrule on the survival of full coverage crowns in ETT}

Endodontically treated teeth often suffer from extensive structural defects because of access cavity preparation, caries, replacement of restoration and trauma. The lack of coronal structure is associated with a lower survival rate of ETT. ${ }^{35}$ In vitro and in vivo studies support the ferrule as the principal factor to increase the fracture resistance of the ETT. ${ }^{12,13,14,15,16,35}$ A prospective clinical study concluded that PFM crowns with less than $50 \%$ of remaining coronal structure have twice the risk of failing compared to teeth with more than $50 \%$ of remaining coronal structure. ${ }^{36}$ A systematic review ${ }^{12}$ included laboratory studies, computer simulations, and clinical trials for the evaluation of the ferrule effect on ETT. Considering the sixty-two articles included, the authors concluded that the presence of a 1.5- to 2-mm ferrule had a positive effect on the fracture resistance of ETT and that providing an adequate ferrule lowers the impact of the post-and-core system, luting agents, and the final restoration on tooth performance. On the other hand, a recent meta-analysis of clinical studies provided no significant difference between the failure risk of glassfiber post-and-core restored teeth with ferrule and that of teeth without ferrule ${ }^{37}$ due to lack of clinical data - only two studies could be included in the analysis.

With the improvement of adhesive dentistry, a paradigm shift to postless approaches in restoring endodontically treated teeth with ferrule is in progress. ${ }^{8,15,16,20,38,39,40}$ Teeth with a minimum of 2 $\mathrm{mm}$ of ferrule have been restored without posts in combination of a resin composite core build-up. ${ }^{15,16,35}$ This technique seems to mimic more closely the structure and biomechanical behavior of a natural tooth, in contrast to the concept of post-and-core build-ups. ${ }^{15}$ Other techniques could be used to improve bond strength and tooth resistance, such as IDS ${ }^{41}$ and indirect 
composite resin..$^{40}$ All aspects of the restoration (crown, adhesive interface, build-up, and tooth) seem to form a cohesive assembly which ideally mimics the properties of the dentin-enamel junction. Modern approaches for posterior and anterior ETT with ferrule have been investigated and proved to be efficient even without the use of a post, as the retention of the crown is granted by the bonding to the ferrule-retained core build-up. ${ }^{12,15,20,35}$ The effect of the ferrule in the survival of ETT has already been proven, therefore sound tooth structure preservation is of paramount importance. Precision in minimally-invasive approaches aids delaying the restorative cycle of death, maintaining ferrule and thus increasing the survival of ETT.

\section{Preserving tooth structure by precision with minimally invasive treatment on ETT}

Precision plays an import role in minimally invasive dentistry. Magnification and precise rotary instrumentation grant the operator the visual accuracy and the fine preparation skills needed in order to maintain healthy dental tissue by only removing solely decayed tissue. ${ }^{42}$

Air driven turbines at high speed do not offer proper tactile sensitivity as can be obtained via low-speed/ high-torque electric handpieces, which is necessary for precise caries removal. Thus, healthy coronal tissue in ETT are mistakenly removed due to the lack of fine tactile skills during caries removal and/or tooth preparation. Many studies have shown that there is a direct correlation between residual coronal structure and tooth survival, ${ }^{4,43}$ therefore, the less coronal dentin and enamel is removed, the higher the survival of ETT. With the aid of an electric handpiece, dentists are more likely to be precise for preparations and caries removal. Especially in compromised teeth, such as ETT, these instruments improve the preservation of underlying tooth structure. Regardless of the extent or severity of the carious lesion, it is now recognized that the outline of the final restoration should follow the three-dimensional shape of the individual lesion in order to preserve and conserve as much tooth structure as possible. ${ }^{44}$ Cavity width and size correlate inversely with fracture strength and positively with the incidence of tooth fracture, respectively. ${ }^{43}$ The modern biomimetic principles rely on the adhesion of materials to safeguard the underlying tooth structure via bonded partial restorations. ${ }^{39,44,45,46}$

Visual accuracy is another factor that influences precision in dentistry. Magnification has a welldocumented history in dentistry. ${ }^{47}$ The benefits of enhanced illumination and magnification on endodontic and restorative procedures has been described. ${ }^{42,48}$ These advantages include a more detailed view of carious and healthy structures. The operator is able to examine more efficiently, detect imperfections and clean the tooth structure without removing healthy tissue. ${ }^{48}$ In addition, superior resolution improves fit accuracy during bonding procedures and restoration delivery. ${ }^{42}$ Combined with caries detecting solutions and light and filters aids, such as fluorescence illumination and cross-polarization filters, magnification enables to detect changes in dentin color and texture, allowing for intelligent and strategic caries removal. The minimally-invasive approach during caries removal and replacement of restorations is of paramount importance to the preservation and and survival of ETT.

\section{Adhesive micro-mechanical retention versus macro- mechanical retention and catastrophic failure of ETT}

ETT often require post-and-core restorations for retention of the crown because of extensive structure loss, according to traditional approaches. ${ }^{49}$ The decision of how to restore ETT without ferrule has become increasingly difficult because of the large number of restorative materials and treatment options..$^{50}$ Traditionally, when the remaining tooth structure is not sufficient to retain a crown (height less than $2 \mathrm{~mm}$ ), a cast post-and-core was indicated to provide retention of the restoration. Generally, they were recommended when minimal or no coronal tooth structure was available for antirotational features or bonding. ${ }^{18}$ However, the traditional cast post-and-core technique is more time-consuming and frequently involves higher laboratory and material costs. ${ }^{49}$ In addition, this approach is associated with catastrophic types of failure since posts present higher elastic modulus compared to dentin..$^{51}$ 
The success of a restored ETT has to be considered not only in view of restoration survival rates but also and most importantly in view of tooth survival rate and re-restorability following failure (failure modes). The most common failure types described in in vitro studies and also observed clinically are either reparable or catastrophic failures. Repairable failures are: cohesive, cohesive/adhesive fracture, minor damage, chipping or cracking of underlying tooth structure. The catastrophic failures, however, involve the tooth/root fracture requiring tooth extraction. ${ }^{13,15,20,25,52}$

Catastrophic root fractures are the most problematic complications of ETT. ${ }^{53}$ A general consensus is that despite the high fracture resistance of the metal posts, stresses concentrate in the root, and are transmitted internally towards the apical level increasing the incidence of root fractures. ${ }^{54,55}$ Opposite results were reported when using glass-fiber posts, presenting similar elastic modulus to that of dentin. ${ }^{56}$ This could improve the stress distribution along the $\operatorname{root}^{57,58}$ and reduce the risk of vertical root fractures..$^{14}$ Fracture strength studies reported tooth fractures to be more "favorable" using glass-fiber posts. Failures with fiber posts happened at lower loads but with higher chances of leaving an an intact root. ${ }^{59,60,61}$

Nowadays, enhanced adhesive procedures are possible through the use of adhesive luting systems in combinations with prefabricated posts and direct core build-ups. ${ }^{20}$ The glass-fiber posts have been widely used, maybe due to the enhanced esthetics and time-efficiency. However, the effect of the post-and-core materials on the fracture strength of ETT have conflicting results. ${ }^{25,53,62,63,64,65}$ Prefabricated glass-fiber posts seem to demonstrate less resistance than cast post-and-core, but present a more favorable failure pattern, providing more reparability., ${ }^{4,49}$ In a 4-year clinical evaluation, the success rate of cast posts-and-cores (cemented approach) was $84 \%$ compared to $95 \%$ when using glass-fiber posts and composite resin cores (adhesive approach); root fractures and crown dislodgements were observed only in the cast post-andcore group. ${ }^{66}$ The literature also confirmed that inserting pre-fabricated posts using an adhesive luting system could result in greater retention, less microleakage, and higher resistance against root fracture. ${ }^{67}$

Studies have demonstrated conflicting results regarding glass-fiber posts. The elastic behavior of this type of post allows a cyclic bending between the crown and core build-up inducing micro-gaps in crown/root interface. ${ }^{64,68,69}$ This gap has been assumed to be the initial failure of the restoration ${ }^{16,69,70}$ and is clinically undetectable allowing leakage between the restoration and tooth. The infiltration may extend into the prepared post space leading to the failure of the restoration. ${ }^{70}$

A meta-analysis on thirteen in vitro studies ${ }^{55}$ evaluated the fracture resistance on ETT treated with cast posts versus glass-fiber posts, and concluded that the cast post group displayed significantly higher fracture resistance than the glass-fiber post group. A recent meta-analysis ${ }^{53}$ indicated the overall incidence rate of root fractures (catastrophic failures) was similar between metal and glass-fiber posts when evaluating seven randomized clinical trials and seven cohort studies. Cloet et al. ${ }^{71}$ in 2017 presented a 5-year follow-up RCT comparing cast post-and-core and fiber-reinforced composite post-andcore systems on ETT with ferrule without statistical difference on survival and success rates. A systematic review in 2017 on ETT failure modes revealed that metal posts are associated with higher risks of root fracture, while glass-fiber posts are associated with higher risks of post/crown/core loss of retention. ${ }^{72}$

In conclusion, recent studies do not agree on the clinical benefit of using pre-fabricated glass-fiber posts rather than cast post-and-core. More clinical studies should be carried out in order to provide more data for a meta-analysis.

\section{No-post approaches}

Due to the significant improvements in adhesive dentistry, principles for the restoration of ETT, particularly those with limited tissue loss, may require revision. The focus of attention should not be on the type of post to be used but rather on the benefit of the post itself. ${ }^{15}$

The original purpose of a post is to retain the core ${ }^{18}$ and not to increase the intrinsic resistance of the root. ${ }^{73}$ Recent in vitro studies demonstrated that the use of posts did not influence the fatigue resistance of posterior teeth $\mathrm{h}^{20,74}$ and neither did in anterior teeth with ferrule. ${ }^{75}$ In fact, for anterior teeth with ferrule, more favorable failure modes were associated with no-post approaches, as the placement of a post was 
always associated with catastrophic failure of the root. ${ }^{15}$ On the other hand, randomized clinical trials have suggested better survival rates of ETT with PFM crowns restored with posts than without posts. ${ }^{76,77}$ The lack of consistency in the literature on the influence of posts in ETT led to some recent investigations of no-post approaches as more biomimetic alternatives: endocrowns versus postless build-ups-and-crowns. ${ }^{78}$

\section{Endocrowns}

It is previously established that the use of a post may cause a catastrophic failure of the tooth, no matter the type of material. ${ }^{53}$ As they are associated with additional removal of sound tissue for post preparation, some studies have been focus on the alternative postless treatment of ETT. ${ }^{38,78,79}$ A postless alternative to treat ETT includes the use of the pulp chamber as an extension of crown itself, the so-called endocrown. This technique consists in combining the crown and core build-up in a single element or "monobloc". ${ }^{19}$ The endocrown requires a simpler and less invasive preparation compared to the multi-step approach of the post-and-core build-up with crown preparation, resulting in decreased treatment time and costs. ${ }^{8,74,80,81}$ Nowadays, endocrowns are even obtained in a single appointment using chairside computer-aided design/computer-aided manufacturing (CAD/CAM) technology.

As they gained popularity, many researchers and clinicians have published highly successful cases describing the clinical steps for the fabrication of endocrowns. ${ }^{78,80,82,83} \mathrm{~A}$ finite element study concluded the endocrown to be a conservative, predictable and clinically feasible restorative approach for endodontically treated maxillary premolars. ${ }^{84}$ According to short-term clinical reports, the survival rate of the endocrowns was $90-95 \%$ in posterior teeth. ${ }^{85,86}$ A recent meta-analysis evaluated studies on endocrowns and concluded they perform similarly or better than conventional treatments using intraradicular posts, direct composite resin or inlay/onlay restorations. ${ }^{38}$ This technique represents a promising and conservative alternative to full crowns for the treatment of posterior nonvital teeth that require long-term protection and stability. ${ }^{80,87}$

There are few studies using endocrowns for the anterior dentition, including a few finite element analyses ${ }^{88,89}$ and one in vitro study. Ramírez-Sebastià et $a{ }^{9}{ }^{90}$ found that the use of endocrowns with adhesive material is sufficient for the restoration of endodontically treated incisors with $2 \mathrm{~mm}$ of ferrule. Anterior endocrowns have not yet been tested in clinical trials. For posterior teeth, a recent clinical study conducted by Belleflamme et al. ${ }^{78}$ evaluated 99 endocrowns made of lithium disilicate or polymer-infiltrated ceramic with a success rate of $99.0 \%$ and $89.9 \%$ respectively for a mean period of 44.7 months. The authors concluded that, when the adhesive technique is properly applied, endocrowns constitute a reliable approach to restore severely damaged molars and premolars, even in the presence of extensive coronal tissue loss or occlusal risk factors, such as bruxism or unfavorable occlusal relationships.

No-post approaches such as endocrowns or postless build-ups-and-crowns are only possible with the application of optimal and reliable adhesion. A very important factor to consider when relying mainly on the adhesive approach is the quality of the adhesion between the restoration and the underlying tooth structure. The adhesion to dentin is considered weaker that adhesion to enamel $\mathrm{l}^{91,92}$ and when restoring ETT, most of the interface is in dentin. A proven strategy to increase the dentin bond strength of indirect restorations is by using the immediate dentin sealing (IDS) technique. ${ }^{41,93,94}$ The studies on postless approaches showing high success rates and outcomes discussed in this review all used IDS in their protocol to optimize bond strength to dentin. ${ }^{15,16,20,78,87}$ Other studies revealed lower success rates using postless build-ups. ${ }^{76,77,95}$ Those results may be explained by the fact that neither IDS technique or bonded restorations were used, but rather cemented PFM crowns to build-ups with different adhesive approaches.

\section{Postless build-ups with crowns}

In recent studies on posterior crowns, the internal walls of the pulp chamber were used to bond the core build-ups, without the use of extra intracanal retention. ${ }^{20,87}$ It was concluded that the post did not increase the fatigue resistance of the endodontically treated molars, but caused more root fractures. ${ }^{20,40}$ Hence, the use of a post can be questioned due to the higher number of catastrophic failures. ${ }^{13,20}$ 
In vitro studies, in spite of being less relevant than clinical trials, have the ability to isolate and investigate a particular variable of interest under strictly standardized conditions. This level of standardization is a significant limitation of clinical trials. Hence, post placement appeared to have no influence in the mechanical performance of endodontically treated incisors, premolars and molars with and without ferrule restored with a bonded crown or endocrown in in vitro studies. ${ }^{13,15,16,87}$ In fact, the placement of a post was associated with more catastrophic failure than the postless approaches in all those studies. Randomized clinical trials (RCT) would be necessary to confirm these in vitro findings with the same adhesive approach. To date, there is no RCT with bonded ceramic crowns as simulated in the aforementioned in vitro studies, but only RCT with PFM crowns over postless build-ups.

Clinical studies evaluated the effect of post placement in teeth restored with PFM crowns. . $6,77,95,96^{-1}$ In these studies, crown dislodgments were very common in teeth restored without post and thus were responsible for the low success rates in postless build-ups. Up to $50 \%$ of postless teeth failures were crown dislodgments. Here again, this finding could be explained by the non-adhesive approach used by the authors when restoring a postless core build-up with a cemented PFM crown. ${ }^{77}$ Such conditions were never studied or suggested by any other in vitro studies on postless approaches, ${ }^{13,15,16,87}$ but instead all of them used bonded all-ceramic crowns or endocrowns.

Hence, a recent meta-analysis ${ }^{97}$ and systematic review ${ }^{98}$ concluded that post placement would be beneficial for the success rate and failure mode of ETT. This conclusion was based exclusively on the same clinical studies in which PFM crowns were used to restore teeth with postless build-ups. ${ }^{77,96}$ Therefore, the scientific evidence (RCT, systematic review and metaanalysis) tends to indicate that post placement increases the success rate of ETT when using PFM crowns, which is a different approach compared to the in vitro studies restoring ETT with all-ceramic bonded crowns and presenting results in favor of the postless approaches. The stress distribution throughout the restoration and restored tooth assembly proved to be different when PFM crowns are used, instead of bonded all-ceramic restorations. ${ }^{99}$ More stress concentration and magnitude were found at the underlying core build-up and tooth structure with PFM. The restoration type may have influenced on the outcome.

Naumann et al. ${ }^{100}$ also evaluated the effect of post placement on the clinical performance of restored ETT in a systematic review. The majority (10 out of 14) of the clinical studies included in this analysis did not show a positive effect of post placement, however a post was advocated when no cavity wall was present. The authors concluded there was no unequivocal clinical evidence to support or reject the use of posts even in no-ferrule situations, either in direct or indirect restorations. Therefore, to date, the literature is not conclusive regarding the need of posts when restoring ETT. More RCT are needed to gain scientific evidence on the clinical performance of ETT restored with and without posts ${ }^{100}$. Another literature review $^{35}$ concurs after analyzing 8 clinical studies: ferrule effect and residual cavity walls are predominant factors with regard to tooth and restoration survival of endodontically treated teeth. Most studies do not confirm a positive effect of post placement for indirect restoration. Therefore, considering the available in vitro studies, clinical trials and systematic reviews, current literature does not provide enough evidence to support the use of a post to restore ETT. ${ }^{101}$

\section{Final considerations}

The survival of ETT is contingent on the residual sound tooth structure that remains after the endodontic access and caries removal are performed, consequently the most important factors upon restoring ETT become the maximum preservation and conservation of enamel, dentin and the dentinoenamel junction. Hence, bonded partial restorations are always preferred over full coverage cementable crowns. ${ }^{21}$ The current goal is to switch approaches from extension for prevention to prevention of extension. ${ }^{102}$ Precision in dentistry obtained by the aid of magnification and electric handpieces as well as bonding optimization provided by proper forms of isolation and IDS are essential steps to protect the remaining tooth structure in a minimally invasive adhesive approach. ${ }^{41,42,93}$

Since the success of restored ETT relies on residual tooth structure, extension for prevention concepts 
should be avoided. In the presence of a ferrule, in vitro and in vivo studies strongly support the fact that posts are not needed to restore ETT. ${ }^{13,15,103}$ Those studies provide further evidence that posts are not needed in order to retain crowns/endocrowns, and are even associated with increased rates of catastrophic failures. ${ }^{20,78} \mathrm{On}$ the other hand, posts are associated with higher survival of ETT when restored with PFM. ${ }^{76,77,95}$ More clinical studies comparing adhesive crowns bonded to postless build-ups or post-and -core build-ups are needed for a better understanding of postless approaches in biomimetic restorative dentistry.

\section{Acknowledgements}

The authors deny any conflict of interest related to this study. This study was supported in part by grants from the National Council for Scientific and Technological Development (CNPq grants 150054/2018-1 to M.A.C).

\section{References}

1. Sedgley $\mathrm{CM}$, Messer $\mathrm{HH}$. Are endodontically treated teeth more brittle? J Endod. 1992 Jul;18(7):332-5. https://doi.org/10.1016/S0099-2399(06)80483-8

2. Papa J, Cain C, Messer HH. Moisture content of vital vs endodontically treated teeth.

Endod Dent Traumatol. 1994 Apr;10(2):91-3. https://doi.org/10.1111/j.1600-9657.1994.tb00067.x

3. Dietschi D, Duc O, Krejci I, Sadan A. Biomechanical considerations for the restoration of endodontically treated teeth: a systematic review of the literature. Part II. Evaluation of fatigue behavior, interfaces, and in vivo studies. Quintessence Int. 2008 Feb;39(2):117-29.

4. Dietschi D, Duc O, Krejci I, Sadan A. Biomechanical considerations for the restoration of endodontically treated teeth: a systematic review of the literature. Part 1. Composition and micro- and macrostructure alterations. Quintessence Int. 2007 Oct;38(9):733-43.

5. Reeh ES, Messer HH, Douglas WH. Reduction in tooth stiffness as a result of endodontic and restorative procedures. J Endod. 1989 Nov;15(11):512-6. https://doi.org/10.1016/S0099-2399(89)80191-8

6. Linn J, Messer HH. Effect of restorative procedures on the strength of endodontically treated molars. J Endod. 1994 Oct;20(10):479-85. https://doi.org/10.1016/S0099-2399(06)80043-9

7. Reeh ES, Douglas WH, Messer HH. Stiffness of endodontically-treated teeth related to restoration technique. J Dent Res. 1989 Nov;68(11):1540-4. https://doi.org/10.1177/00220345890680111401

8. Magne P, Carvalho AO, Bruzi G, Anderson RE, Maia HP, Giannini M. Influence of no-ferrule and no-post buildup design on the fatigue resistance of endodontically treated molars restored with resin nanoceramic CAD/ CAM crowns. Oper Dent. 2014 Nov-Dec;39(6):595-602. https://doi.org/10.2341/13-004-L
9. Panitvisai P, Messer HH. Cuspal deflection in molars in relation to endodontic and restorative procedures. J Endod. 1995 Feb;21(2):57-61. https://doi.org/10.1016/S0099-2399(06)81095-2

10. Taha NA, Palamara JE, Messer HH. Cuspal deflection, strain and microleakage of endodontically treated premolar teeth restored with direct resin composites. J Dent. 2009 Sep;37(9):724-30. https://doi.org/10.1016/i.jdent.2009.05.027

11. Magne P, Belser U. Bonded porcelain restorations in the anterior dentition: a biomimetic approach. Batavia, III: Quintessence; 2003. Understanding the intact tooth and the biomimetic principle. p. 23-55.

12. Juloski J, Radovic I, Goracci C, Vulicevic ZR, Ferrari M. Ferrule effect: a literature review. J Endod. 2012 Jan;38(1):11-9. https://doi.org/10.1016/i.joen.2011.09.024

13. Zicari F, Van Meerbeek B, Scotti R, Naert I. Effect of ferrule and post placement on fracture resistance of endodontically treated teeth after fatigue loading. J Dent. Elsevier Ltd; 2013 Mar;41(3):207-15. https://doi.org/10.1016/i.jdent.2012.10.004

14. Santos-Filho PC, Veríssimo C, Soares PV, Saltarelo RC, Soares CJ, Marcondes Martins LR. Influence of ferrule, post system, and length on biomechanical behavior of endodontically treated anterior teeth. J Endod. 2014 Jan;40(1):119-23. https://doi.org/10.1016/i.joen.2013.09.034

15. Magne P, Lazari PC, Carvalho MA, Johnson T, Del Bel Cury AA. Ferrule-effect dominates over use of a fiber post when restoring endodontically treated incisors: an in vitro study. Oper Dent. 2017 Jul/Aug;42(4):396-406. https://doi.org/10.2341/16-243-L

16. Lazari PC, Carvalho MA, Del Bel Cury AA, Magne P. Survival of extensively damaged endodontically treated incisors restored with different types of posts-and-core foundation restoration material. J Prosthet Dent. 2018 May; 19(5):769-76. https://doi.org/10.1016/i.prosdent.2017.05.012 
17. Opdam NJ, Bronkhorst EM, Loomans BA, Huysmans MC. 12-year survival of composite vs. amalgam restorations. J Dent Res. 2010 Oct;89(10):1063-7. https://doi.org/10.1177/0022034510376071

18. Schwartz RS, Robbins JW. Post placement and restoration of endodontically treated teeth: a literature review. J Endod. 2004 May;30(5):289-301. https://doi.org/10.1097/00004770-200405000-00001

19. Pissis P. Fabrication of a metal-free ceramic restoration utilizing the monobloc technique. Pract Periodontics Aesthet Dent. 1995 Jun-Jul;7(5):83-94.

20. Magne P, Goldberg J, Edelhoff D, Güth JF. Composite resin core buildups with and without post for the restoration of endodontically treated molars without ferrule. Oper Dent. 2016 Jan-Feb;41(1):64-75. https://doi.org/10.2341/14-258-L

21. Elderton RJ. Restorations without conventional cavity preparations. Int Dent J. 1988 Jun;38(2):112-8.

22. Simonsen RJ. New Materials on the horizon. J Am Dent Assoc. 1991 Jul;122(7):24-31. https://doi.org/10.14219/jada.archive.1991.0217

23. Opdam N, Frankenberger R, Magne P. From "direct versus indirect" toward an integrated restorative concept in the posterior dentition. Oper Dent. 2016 Sep;41 S7:S27-34. https://doi.org/10.2341/15-126-LIT

24. Yuan K, Niu C, Xie Q, Jiang W, Gao L, Huang Z et al. Comparative evaluation of the impact of minimally invasive preparation vs. conventional straight-line preparation on tooth biomechanics: a finite element analysis. Eur J Oral Sci. 2016 Dec;124(6):591-6. https://doi.org/10.1111/eos.12303

25. Silva NR, Raposo LH, Versluis A, Fernandes-Neto AJ, Soares CJ. The effect of post, core, crown type, and ferrule presence on the biomechanical behavior of endodontically treated bovine anterior teeth. J Prosthet Dent. 2010 Nov;104(5):30617. https://doi.org/10.1016/S0022-3913(10)60146-1

26. Fennis WM, Kuijs RH, Kreulen CM, Verdonschot N, Creugers $\mathrm{NH}$. Fatigue resistance of teeth restored with cuspal-coverage composite restorations. Int J Prosthodont. 2004 MayJun;17(3):313-7.

27. Skupien JA, Cenci MS, Opdam NJ, Kreulen CM, Huysmans MC, Pereira-Cenci T. Crown vs. composite for post-retained restorations: a randomized clinical trial. J Dent. 2016;48:34 9. https://doi.org/10.1016/i.jdent.2016.03.007

28. Fedorowicz Z, Carter B, Souza RF, Chaves CAL, Nasser $M$, Sequeira-Byron P. Single crowns versus conventional fillings for the restoration of root filled teeth. Cochrane Database Syst Rev. 2012 May;(5): CD009109 https://doi.org/10.1002/14651858.CD009109.pub2

29. Murphy F, McDonald A, Petrie A, Palmer G, Setchell D. Coronal tooth structure in root-treated teeth prepared for complete and partial coverage restorations. J Oral Rehabil. 2009 Jun;36(6):451-61. https://doi.org/10.1111/i.1365-2842.2009.01952.x
30. Suksaphar W, Banomyong D, Jirathanyanatt $T$, Ngoenwiwatkul Y. Survival rates against fracture of endodontically treated posterior teeth restored with fullcoverage crowns or resin composite restorations: a systematic review. Restor Dent Endod. 2017 Aug;42(3):157-67. https://doi.org/10.5395/rde.2017.42.3.157

31. Mannocci F, Bertelli E, Sherriff M, Watson TF, Ford TR. Threeyear clinical comparison of survival of endodontically treated teeth restored with either full cast coverage or with direct composite restoration. J Prosthet Dent. 2002 Sep;88(3):297301. https://doi.org/10.1067/mpr.2002.128492

32. Cagidiaco MC, Radovic I, Simonetti M, Tay F, Ferrari $M$. Clinical performance of fiber post restorations in endodontically treated teeth: 2-year results. Int J Prosthodont. 2007 May-Jun;20(3):293-8.

33. Dammaschke T, Nykiel K, Sagheri D, Schäfer E. Influence of coronal restorations on the fracture resistance of root canal-treated premolar and molar teeth: a retrospective study. Aust Endod J. 2013 Aug;39(2):48-56. https://doi.org/10.1111/aej.12002

34. Krejci I, Duc O, Dietschi D, Campos E. Marginal adaptation, retention and fracture resistance of adhesive composite restorations on devital teeth with and without posts. Oper Dent. 2003 Mar-Apr;28(2):127-35.

35. Naumann M, Schmitter M, Frankenberger R, Krastl G. "Ferrule comes first. post is second!" Fake news and alternative facts? A systematic review. J Endod. 2018 Feb;44(2):212-9. https://doi.org/10.1016/i.joen.2017.09.020

36. Ferrari M, Sorrentino R, Juloski J, Grandini S, Carrabba $M$, Discepoli $N$ et al. Post-retained single crowns versus fixed dental prostheses: a 7-year prospective clinical study. J Dent Res. 2017 Dec;96(13):1490-7. https://doi.org/10.1177/0022034517724146

37. Yang $A$, Lamichhane $A, X \cup C$. Remaining coronal dentin and risk of fiber-reinforced composite post-core restoration failure: a meta-analysis. Int J Prosthodont. 2015 MayJun;28(3):258-64. https://doi.org/10.11607/ijp.4157

38. Sedrez-Porto JA, Rosa WLO, Silva AF, Münchow EA, PereiraCenci T. Endocrown restorations: a systematic review and meta-analysis. J Dent. 2016 Sep;52:8-14. https://10.1016/i. ident.2016.07.005

39. Magne P. Pascal Magne: 'It should not be about aesthetics but tooth-conserving dentistry'. Interview by Ruth Doherty. Br Dent J. 2012 Aug;213(4):189-91. https://doi.org/10.1038/sj.bdj.2012.769

40. Güth JF, Edelhoff D, Goldberg J, Magne P. CAD/ CAM polymer vs direct composite resin core buildups for endodontically treated molars without ferrule. Oper Dent. 2016 Jan-Feb;41(1):53-63. https://doi.org/10.2341/14-256-L

41. Magne P. Immediate dentin sealing: a fundamental procedure for indirect bonded restorations.

J Esthet Restor Dent. 2005;17(3):144-54. https://doi.org/10.1111/j.1708-8240.2005.tb00103.x 
42. Browet $S$, Gerdolle D. Precision and security in restorative dentistry: the synergy of isolation and magnification. Int J Esthet Dent. 2017;12(2):172-85.

43. Patel DK, Burke FJ. Fractures of posterior teeth: a review and analysis of associated factors. Prim Dent Care. 1995 Mar;2(1):6-10.

44. Ferraris F. Posterior indirect adhesive restorations (PIAR): preparation designs and adhesthetics clinical protocol. Int J Esthet Dent. 2017;12(4):482-502.

45. Zarow M, Devoto W, Saracinelli M. Reconstruction of endodontically treated posterior teeth: with or without post? Guidelines for the dental practitioner. Eur J Esthet Dent. 2009;4(4):312-27.

46. Veneziani M. Posterior indirect adhesive restorations: updated indications and the Morphology Driven Preparation Technique. Int J Esthet Dent. 2017;12(2):204-30.

47. Castellucci A. Magnification in endodontics: the use of the operating microscope. Pract Proced Aesthet Dent. 2003 Jun;15(5):377-84.

48. Bowers DJ, Glickman GN, Solomon ES, He J. Magnification's effect on endodontic fine motor skills. J Endod. 2010;36(7):1135-8. https://doi.org/10.1016/j.joen.2010.03.003

49. Heydecke G, Peters MC. The restoration of endodontically treated, single-rooted teeth with cast or direct posts and cores: a systematic review. J Prosthet Dent. 2002 Apr;87(4):380-6. https://doi.org/10.1067/mpr.2002.123848

50. Garbin $C A$, Spazzin AO, Meira-Júnior AD, Loretto SC, Lyra AM, Braz R. Biomechanical behaviour of a fractured maxillary incisor restored with direct composite resin only or with different post systems. Int Endod J. 2010 Dec;43(12):1098-107. https://doi.org/10.1111/j.1365-2591.2010.01782.x

51. Torbjörner A, Fransson B. A literature review on the prosthetic treatment of structurally compromised teeth. Int J Prosthodont. 2004;17(3):369-76.

52. Zicari F, Van Meerbeek B, Scotti R, Naert I. Effect of fibre post length and adhesive strategy on fracture resistance of endodontically treated teeth after fatigue loading. J Dent. 2012 Apr;40(4):312-21. https://doi.org/10.1016/i.jdent.2012.01.006

53. Figueiredo FE, Martins-Filho PR, Faria-E-Silva AL. Do metal post-retained restorations result in more root fractures than fiber post-retained restorations? A systematic review and meta-analysis. J Endod. 2015 Mar;41(3):309-16. https://doi.org/10.1016/i.joen.2014.10.006

54. Goracci C, Ferrari M. Current perspectives on post systems: a literature review. Aust Dent J. 2011 Jun;56 Suppl 1:77-83. https://doi.org/10.1111/j.1834-7819.2010.01298.x

55. Zhou L, Wang Q. Comparison of fracture resistance between cast posts and fiber posts : a metaanalysis of literature. J Endod. 2013;39(1):11-5. https://doi.org/10.1016/i.joen.2012.09.026
56. Plotino G, Grande NM, Bedini R, Pameijer CH, Somma F. Flexural properties of endodontic posts and human root dentin. Dent Mater. 2007 Sep;23(9):1129-35. https://doi.org/10.1016/i.dental.2006.06.047

57. Mezzomo LA, Corso L, Marczak RJ, Rivaldo EG. Three-dimensional FEA of effects of two doweland-core approaches and effects of canal flaring on stress distribution in endodontically treated teeth. J Prosthodont. 2011 Feb;20(2):120-9. https://doi.org/10.1111/j.1532-849X.2010.00669.x

58. Watanabe MU, Anchieta RB, Rocha EP, Kina S, Almeida EO, Freitas Junior AC et al. Influence of crown ferrule heights and dowel material selection on the mechanical behavior of root-filled teeth: a finite element analysis. J Prosthodont. 2012 Jun;21(4):304-11. https://doi.org/10.1111/j.1532-849X.2011.00832.x

59. Pontius $\mathrm{O}$, Nathanson D, Giordano R, Schilder H, Hutter JW. Survival rate and fracture strength of incisors restored with different post and core systems and endodontically treated incisors without coronoradicular reinforcement. J Endod. 2002 Oct;28(10):710-5. https://doi.org/10.1097/00004770-200210000-00008

60. Newman MP, Yaman P, Dennison J, Rafter M, Billy E. Fracture resistance of endodontically treated teeth restored with composite posts. J Prosthet Dent. 2003 Apr;89(4):360-7. https://doi.org/10.1067/mpr.2003.75

61. Akkayan B, Gülmez T. Resistance to fracture of endodontically treated teeth restored with different post systems. J Prosthet Dent. 2002 Apr;87(4):431-7. https://doi.org/10.1067/mpr.2002.123227

62. Sterzenbach G, Franke A, Naumann M. Rigid versus flexible dentine-like endodontic posts: clinical testing of a biomechanical concept: seven-year results of a randomized controlled clinical pilot trial on endodontically treated abutment teeth with severe hard tissue loss. J Endod. 2012;38(12):1557-63. https://doi.org/10.1016/i.joen.2012.08.015

63. Sahafi A, Peutzfeldt A, Ravnholt G, Asmussen E, Gotfredsen K. Resistance to cyclic loading of teeth restored with posts. Clin Oral Investig. 2005 Jun;9(2):84-90. https://doi.org/10.1007/s00784-004-0299-7

64. McLaren JD, McLaren Cl, Yaman P, Bin-Shuwaish MS, Dennison JD, McDonald NJ. The effect of post type and length on the fracture resistance of endodontically treated teeth. J Prosthet Dent. 2009 Mar;101(3):174-82. https://doi.org/10.1016/S0022-3913(09)60024-X

65. Ozcan M, Valandro LF. Fracture strength of endodonticallytreated teeth restored with post and cores and composite cores only. Oper Dent. 2009 Jul-Aug;34(4):429-36. https://doi.org/10.2341/08-110

66. Ferrari M, Vichi A, García-Godoy F. Clinical evaluation of fiber-reinforced epoxy resin posts and cast post and cores. Am J Dent. 2000 May;13(Spec No):15B-8B. 
67. Koch AT, Binus SM, Holzschuh B, Petschelt A, Powers JM, Berthold C. Restoration of endodontically treated teeth with major hard tissue loss - influence of post surface design on pull-out bond strength of fiber-reinforced composite posts. Dent Traumatol. 2014 Aug;30(4):270-9. https://doi.org/10.1111/edt.12089

68. Sidoli GE, King PA, Setchell DJ. An in vitro evaluation of a carbon fiber-based post and core system. J Prosthet Dent. 1997 Jul;78(1):5-9. https://doi.org/10.1016/S0022-3913(97)70080-5

69. Kishen A. Mechanisms and risk factors for fracture predilection in endodontically treated teeth. Endod Topics. 2006;13(1):57-83. https://doi.org/10.1111/j.1601-1546.2006.00201.x

70. Freeman MA, Nicholls JI, Kydd WL, Harrington GW. Leakage associated with load fatigue-induced preliminary failure of full crowns placed over three different post and core systems. J Endod. 1998 Jan;24(1):26-32. https://doi.org/10.1016/S0099-2399(98)80208-2

71. Cloet E, Debels E, Naert I. Controlled clinical trial on the outcome of glass fiber composite cores versus wrought posts and cast cores for the restoration of endodontically treated teeth: a 5-year follow-up study. Int J Prosthodont. 2017 Jan/ Feb;30(1):71-9. https://doi.org/10.11607/ijp.4861

72. Marchionatti AM, Wandscher VF, Rippe MP, Kaizer $O B$, Valandro LF. Clinical performance and failure modes of pulpless teeth restored with posts: a systematic review. Braz Oral Res. 2017 Jul;31(0):e64. https://doi.org/10.1590/1807-3107bor-2017.vol31.0064

73. Rasimick BJ, Wan J, Musikant BL, Deutsch AS. A review of failure modes in teeth restored with adhesively luted endodontic dowels. J Prosthod. 2010;19:639-46. https://doi.org/10.1111/j.1532-849X.2010.00647.x

74. Biacchi GR, Basting RT. Comparison of fracture strength of endocrowns and glass fiber post-retained conventional crowns. Oper Dent. 2012 Mar-Apr;37(2):130-6. https://doi.org/10.2341/11-105-L

75. Magne P, Lazari PC, Carvalho MA, Jhonson T, Del Bel Cury AA. Ferrule-effect dominates over use of a fiber post when restoring endodontically-treated incisors with composite build-up and ceramic crown: an invitro study. Oper Dent. 2017. Jul/Ago;42(4):396-406. https://doi.org/10.2341/16-243-L

76. Guldener KA, Lanzrein CL, Siegrist Guldener BE, Lang NP, Ramseier CA, Salvi GE. Long-term clinical outcomes of endodontically treated teeth restored with or without fiber post-retained singleunit restorations. J Endod. 2017 Feb;43(2):188-93. https://doi.org/10.1016/i.joen.2016.10.008.

77. Ferrari M, Vichi A, Fadda GM, Cagidiaco MC, Tay FR, Breschi $L$ et al. A randomized controlled trial of endodontically treated and restored premolars. J Dent Res. 2012 Jul;91(7 Suppl):72S-8S. https://doi.org/10.1177/0022034512447949
78. Belleflamme MM, Geerts SO, Louwette MM, Grenade CF, Vanheusden AJ, Mainjot AK. No post-no core approach to restore severely damaged posterior teeth: an up to 10 -year retrospective study of documented endocrown cases. J Dent. 2017 Aug;63:1-7. https://doi.org/10.1016/i.jdent.2017.04.009

79. Rocca GT, Sedlakova P, Saratti CM, Sedlacek R, Gregor L, Rizcalla $N$ et al. Fatigue behavior of resinmodified monolithic CAD-CAM RNC crowns and endocrowns. Dent Mater. 2016 Dec;32(12):e338-50. https://doi.org/10.1016/i.dental.2016.09.024

80. Lander E, Dietschi D. Endocrowns: a clinical report. Quintessence Int. 2008 Feb;39(2):99-106.

81. Rocca GT, Saratti CM, Poncet A, Feilzer AJ, Krejci I. The influence of FRCs reinforcement on marginal adaptation of CAD/CAM composite resin endocrowns after simulated fatigue loading. Odontology. 2016 May; 104(2):220-32. https://doi.org/ 10.1007/s10266-015-0202-9

82. Biacchi GR, Mello B, Basting RT. The endocrown: an alternative approach for restoring extensively damaged molars. J Esthet Restor Dent. 2013 Dec;25(6):383-90. https://doi.org/10.1111/jerd.12065

83. Fages $M$, Bennasar B. The endocrown: a different type of all-ceramic reconstruction for molars. J Can Dent Assoc. 2013;79:d140.

84. Lin $\mathrm{CL}$, Chang $\mathrm{YH}$, Chang $\mathrm{CY}$, Pai CA, Huang SF. Finite element and Weibull analyses to estimate failure risks in the ceramic endocrown and classical crown for endodontically treated maxillary premolar. Eur J Oral Sci. 2010 Feb;118(1):87-93. https://doi.org/10.1111/j.1600-0722.2009.00704.x

85. Bernhart J, Bräuning A, Altenburger MJ, Wrbas KT. Cerec 3D endocrowns: two-year clinical examination of CAD/CAM crowns for restoring endodontically treated molars. Int J Comput Dent. 2010;13(2):141-54.

86. Bindl A, Mörmann WH. Clinical evaluation of adhesively placed Cerec endo-crowns after 2 years: preliminary results. J Adhes Dent. 1999;1(3):255-65

87. Gresnigt MM, Özcan M, Houten ML, Schipper L, Cune MS. Fracture strength, failure type and Weibull characteristics of lithium disilicate and multiphase resin composite endocrowns under axial and lateral forces. Dent Mater. 2016 May;32(5):607-14. https://doi.org/10.1016/j.dental.2016.01.004

88. Aversa R, Apicella D, Perillo L, Sorrentino R, Zarone F, Ferrari M et al. Non-linear elastic three-dimensional finite element analysis on the effect of endocrown material rigidity on alveolar bone remodeling process. Dent Mater. 2009 May;25(5):678-90. https://doi.org/10.1016/i.dental.2008.10.015

89. Zarone F, Sorrentino R, Apicella D, Valentino B, Ferrari M, Aversa $R$ et al. Evaluation of the biomechanical behavior of maxillary central incisors restored by means of endocrowns compared to a natural tooth: a 3D static linear finite elements analysis. Dent Mater. 2006 Nov;22(11):1035-44. https://doi.org/10.1016/j.dental.2005.11.034 
- Current options concerning the endodontically-treated teeth restoration with the adhesive approach

90. Ramírez-Sebastià A, Bortolotto T, Cattani-Lorente M, Giner L, Roig M, Krejci I. Adhesive restoration of anterior endodontically treated teeth: influence of post length on fracture strength. Clin Oral Investig. 2014;18(2):545-54. https://doi.org/10.1007/s00784-013-0978-3

91. Manuja N, Nagpal R, Pandit IK. Dental adhesion: mechanism, techniques and durability. J Clin Pediatr Dent. 2012;36(3):223-34. https://doi.org/10.17796/jcpd.36.3.68805rl1r037m063

92. De Munck J, Mine A, Poitevin A, Van Ende A, Cardoso MV, Van Landuyt $\mathrm{KL}$ et al. Meta-analytical review of parameters involved in dentin bonding. J Dent Res. 2012 Apr;91(4):3517. https://doi.org/10.1177/0022034511431251

93. Magne P, Kim TH, Cascione D, Donovan TE. Immediate dentin sealing improves bond strength of indirect restorations. J Prosthet Dent. 2005 Dec;94(6):511-9. https://doi.org/10.1016/i.prosdent.2005.10.010

94. Gresnigt MM, Cune MS, Roos JG, Özcan M. Effect of immediate and delayed dentin sealing on the fracture strength, failure type and Weilbull characteristics of lithiumdisilicate laminate veneers. Dent Mater. 2016 Apr;32(4):e73-81. https://doi.org/10.1016/i.dental.2016.01.001

95. Salvi GE, Siegrist Guldener BE, Amstad T, Joss A, Lang NP. Clinical evaluation of root filled teeth restored with or without post-and-core systems in a specialist practice setting. Int Endod J. 2007 Mar;40(3):209-15. https://doi.org/10.1111/j.1365-2591.2007.01218.x

96. Ferrari M, Cagidiaco MC, Grandini S, De Sanctis M, Goracci C. Post placement affects survival of endodontically treated premolars. J Dent Res. 2007 Aug;86(8):729-34. https://doi.org/10.1177/154405910708600808
97. Zhu Z, Dong XY, He S, Pan X, Tang L. Effect of post placement on the restoration of endodontically treated teeth: a systematic review. Int J Prosthodont. 2015 SepOct;28(5):475-83. https://doi.org/10.11607/ijp.4120

98. Aurélio IL, Fraga S, Rippe MP, Valandro LF. Are posts necessary for the restoration of root filled teeth with limited tissue loss? A structured review of laboratory and clinical studies. Int Endod J. 2014;2015:827-35.

99. Abuelenain DA, Ajaj R, El-Bab El, Hammouda MM. Comparison of stresses generated within the supporting structures of mandibular second molars restored with different crown materials: 3-D finite element analysis (FEA). J Prosthodont. 2015 Aug;24(6):484-93. https://doi.org/10.1111/jopr.12240

100. Naumann M, Schmitter M, Krastl G. Postendodontic restoration: endodontic post-and-core or no post at all? J Adhes Dent. 2018;20(1):19-24. https://doi.org/10.3290/i.jad.a39961

101. Brignardello-Petersen R. Serious limitations in a systematic review about the effects of placing posts in endodontically treated teeth result in evidence that is not useful in making decisions. J Am Dent Assoc. 2018 Jun;149(6):e96. https://doi.org/10.1016/i.adaj.2018.01.027

102. Burke FJ. From extension for prevention to prevention of extension: (minimal intervention dentistry). Dent Update. 2003 Nov;30(9):492-8. https://doi.org/10.12968/denu.2003.30.9.492

103. Bitter K, Noetzel J, Stamm O, Vaudt J, Meyer-Lueckel H, Neumann $\mathrm{K}$ et al. Randomized clinical trial comparing the effects of post placement on failure rate of postendodontic restorations: preliminary results of a mean period of 32 months. J Endod. 2009 Nov;35(11):1477-82. https://doi.org/10.1016/i.joen.2009.07.026 